\section{Making the cases for ethics}

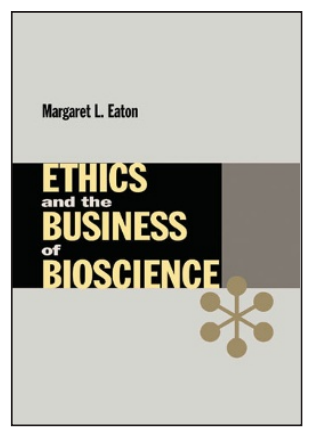

\section{Ethics and the Business of Bioscience}

by Margaret L. Eaton

Stanford University Press, 2004

552 pp. paperback, $\$ 34.95$; cloth, $\$ 80$

ISBN 0804742502

\section{Reviewed by Rahul K Dhanda}

Dedicated to the responsible delivery of medical care, as well as the thoughtful pursuit of biological knowledge, bioethics has for decades been a vibrant field that has grown to touch almost every aspect of life science. The advent of the Human Genome Project in the mid-1980s boosted the discipline even more, dedicating roughly $3 \%-5 \%$ of its multibillion dollar budget to the study of the ethical, legal and social issues surrounding genetic technologies.

The marvels of genomics and other biotechnologies may have pushed ethical boundaries, but they also inspired the corporate opportunism that has since leveraged new discoveries, venture capital investments, stock market speculation and all of the trappings of capitalism. These examples do not exhaust the epiphenomena that have surfaced: another that requires special attention is the fear that corresponds with the 'profit-over-responsibility' charge that many critics level against corporations. Concerns over corporate motives become even more acute when the potential abuses of the science of life are coincident with the pursuit of capital. Too little has been written about this topic, and Margaret Eaton has acted to correct this lacuna with her book Ethics and the Business of Bioscience.

Eaton has collected an impressive amount of information-interviews at leading biotechnology companies and research to bring the academic fields of business ethics and bioethics together with real world experience- to construct a series of case studies for use by students of biotechnology, from industry professionals to college undergraduates. The result is a book that is as thorough as it is informative.

Examining a diverse range of firms, the author tackles various technologies and issues-from stem cells to genetically modified foods to justice in access to technologies. Any student of corporate biotechnology, business ethics and bioethics is likely to find useful information, as the text meticulously deconstructs the challenges created by, and strategies to confront, the ethical issues faced by biotech firms. The analysis of Monsanto's experience with recombinant bovine somatotropin

Rahul K. Dhanda is at the MIT Sloan School of Management, the Jamestown Project at Yale Law School, and Interleukin Genetics, and is chair of the bioethics advisory group of the Massachusetts Biotechnology Council. He is the author of Guiding Icarus: Merging Bioethics with Corporate Interests (Wiley-Liss, New York, 2002).
(Posilac), a growth hormone that stimulated milk production in cows, opens the analytic portion of the text, and it presages the plight the company would face when it released genetically modified (GM) seeds. Although the latter case has received more attention, the Posilac incident raised a similar furor over whether milk derived from treated cows should contain a label detailing that fact.

Ethical issues and corporate strategies around genetic testing, access to drugs and many other rich examples fill the book, but these may reflect a minor drawback in that most of these cases are high-profile incidents-occurrences that are likely to be familiar to most interested readers. Unfortunately, this is a necessary and unavoidable tactic. Because ethics is not always readily recognized as a natural complement to the formal components of the business world (e.g., finance and $\mathrm{R} \& \mathrm{D})$, any attempt to examine it in a corporate context must tread on familiar examples. Thus, these examples may not convince the reader of the book's noblest intent - that the complicated issues facing corporate biotechnology are present even in the most mundane of settings. That the example of fair access to AIDS therapy seems so dire and so different from, say, access to basic healthcare may dissuade a firm developing a new rheumatoid arthritis therapy from seeing the relevance of the higher-profile case. The cases differ, but they touch upon common questions throughout the industry. All such cases involve fundamental questions of the social significance of health, just access to healthcare, and the balance between fair profits and corporate social responsibility, and it would be a shame if those commonalities were lost in the glitz of highprofile cases.

Although as many people as possible ought to be educated about the ethical issues that surround the healthcare technologies that touch their lives, Eaton has created a book targeted at those who need this education most-namely, managers of biotech companies. More precisely, the public needs these individuals to be educated. However, she has also displayed, by virtue of her choice of companies, that the belief that ethics considerations are beyond the competency of corporate operations is untrue. Some may argue that the chosen examples are more the exception than the rule, but the book is heartening in that it highlights numerous industry representatives who are aware of the significance of ethical issues. "I don't think you can be involved in genetics and not in ethical issues," says Elliott Hillback Jr. of Genzyme. Steven Holtzman (now CEO of Infinity Pharmaceuticals) discusses his own experiences at Millennium Pharmaceuticals and the importance of ethics to his position as chief business officer. According to him, "Written into my job description — literally — was a mandate to bring an awareness of sensitive ethical issues to the staff that our work would raise."

Experiences such as these pepper the book, but it is hard to claim from these cases that such attitudes are the rule rather than the exception. It is this point that highlights the greatest value of Ethics and the Business of Bioscience. In the wake of the scandals surrounding Enron, ImClone, WorldCom and the resulting Sarbanes-Oxley legislation, ethics and corporate responsibility are receiving greater attention. However, until recently, anyone searching for resources on ethics and bioscience had to dig deeply into the literature to find it. Hopefully, Margaret Eaton's book will find its way to the business schools, libraries and corporations where many interested readers are still searching for this knowledge. 